Available online on 15.02.2020 at http://jddtonline.info
Open Access to Pharmaceutical and Medical Research
unrestricted non-commercial use, provided the original work is properly cited

Open Access

Research Article

\title{
Optimization of the Yield Extraction of Essential Thyme Oil through Response Surface Method (RSM)
}

\author{
Fadila Ayati' ${ }^{1}$, Saida Touzouirt ${ }^{2 *}$, Lila Aomari' ${ }^{1}$, Chabha Sehaki ${ }^{1}$ \\ ${ }^{1}$ Département de chimie, Université Mouloud Mammeri de Tizi-Ouzou, BP 17 Tizi-Ouzou, Algérie \\ 2 Département de Génie des procédés, Faculté de Technologie, université M’Hamed Bougara, Boumerdes, Algérie
}

\begin{abstract}
The objective of this study is the optimization of the extraction yield of essential Thyme capitatus oil using hydrodistillation Clevenger in order to industrialize the scale and increase the extrapolation possibility. The optimal conditions are determined using central composite designs (CCD). Nine runs were performed by varying the extraction time and the plant material form (i.e. ground and unground). The ratio of the mass/volume was considered constant during the experiments. The optimum yield was obtained for unground form with $1.6078 \%$ during one hour of extraction. The results of the extracted oil showed that the relative density values and the refractive index comply with international standards
\end{abstract}

Keywords: hydrodistillation Clevenger, essential oil, Thymus capitatus, optimization, experimental design.

Article Info: Received 24 Nov 2019; $\quad$ Review Completed 18 Jan 2020; Accepted 29 Jan 2020; Available online 15 Feb 2020

Cite this article as:

Ayati F, Touzouirt S, Aomari L, Sehaki C, Optimization of the Yield Extraction of Essential Thyme Oil through Response Surface Method (RSM), Journal of Drug Delivery and Therapeutics. 2020; 10(1-s):154-158

http://dx.doi.org/10.22270/jddt.v10i1-s.3886

*Address for Correspondence:

Saida Touzouirt, Département de Génie des procédés, Faculté de Technologie, université M’Hamed Bougara, Boumerdes, Algérie

\section{INTRODUCTION}

Because of several implications of the essential oils of medicinal plants, improving their productivity becomes the major scientific community concern. The oil in medicinal plants is considered a limited and artisanal production in Algeria, as well as in some Mediterranean countries that possess appreciable natural resources.

For this purpose, gainful and beneficial extraction methods must be found. At the same time, it offers pride to Algerian communities though the awareness of the rich plant heritage that Algeria possesses. For that reason, the objective of this work is to model some of the extraction conditions of essential oils that could give benefit and progress to industrial production scale.

The studied Thymus has 11 species [1]. The Thymus Capitatus is a member of the Lamiaceae family, abundant in northeastern Algeria, which is commonly used in local medicinal traditions. Thyme oil is often considered as the most active essential oils that gives a good alternative to antibiotic medicine[2-4] because of its rich composition of alcohols, phenols, aldehydes, ketones, esters and phenyl propane derivatives. Besides, the adequate choice of apparatus and the process under defined operating conditions provide an optimal extraction yield.
In the present study, essential oils are produced by Clevenger hydrodistillation that appeared to be the best method to maintain both the perfumes of the aromatic plants and their therapeutic capacities. Hence, the hydro distillation method is the most commonly used method on an industrial scale for the essential oil with a simple and affordable technology $[5,6]$. In addition, modeling through the design of experiments methodology is often indicated [7, 8]. Olugbenga et al [9] used a full factorial design for the optimization of the essential oil extraction of Cymbopogon citratus.

In this study, the response surface method was applied. The central composite design was chosen for its utility and simplicity. These design of experiments are preparing for a sequential approach, allowing great flexibility in the addition of other tests, if the analyzes of the results obtained prove unsatisfactory. On the other hand, they prove to be very useful in an approach to optimize the response. They are the simplest to interpret and show most cost-effective ratio [10]. Two factors that influence the yield and are easily understandable, but seldom mentioned in the literature, are the extraction time and the plant material form (ground and unground). The extraction time influencing the quality and the quantity of the oil has a significant impact on the economic side of production. Saidj (2007) [11] confirmed that the process is no longer economic after about one hour of extraction with different composition. The second factor is 
the plant's material form, which determines the maximum yield. The ground plants form is highly recommended because it allows optimal productivity, which is mainly related to cover with small glands full of essential oils.

\section{MATERIAL AND METHODS}

\subsection{Biological Material}

At the end of April 2018 and during the flowering period, the thyme was harvested in the western Kabylie region (located in east-central Algeria). The plant was washed and then dried in the shade for around 10 days [12]. The identification of the plant was carried out at the department of Biology Faculty of Biological and Agricultural Sciences- at Mouloud Mammeri University of Tizi-Ouzou (MMUTO).

\subsection{Methods}

\subsubsection{Central composite design}

In this study, the central composite design consists of twolevel factors (Table 1). The extraction yield of the essential oil represents the response $\mathrm{Y}$ that is closely related to the extraction time and the plant form. Extraction time is proportional to the extraction yield; it is a quantitative variable and considered as an important factor because it affects the quality and the oil's composition. The domain of the experiment was determined according to the recommendations of literature [13-15]. The second qualitative variable "the plant form" (both ground and unground) is chosen to highlight the influence of grinding on the extraction yield. The experiment matrix as well as the statistical analysis of the results was made using MODDE software, version 6 .

Table 1: Domain of variable for the central composite design

\begin{tabular}{cccc}
\hline Factors/levels & $\mathbf{( - 1 )}$ & $\mathbf{0}$ & $\mathbf{( + 1 )}$ \\
\hline Extraction time (min) & 60 & 120 & 180 \\
Plant form & unground & ground & ground \\
\hline
\end{tabular}

The number of trials $\mathrm{N}$ is taken from full factorial design $\mathrm{N}_{\mathrm{F}}=$ $2 \mathrm{k}$ ). Three additional points were added to the center of the domain $\left(\mathrm{N}_{0}\right)$ in order to evaluate the reproducibility of the response and the experimental error and others points "Axial" for the quantitative factor.

$\mathrm{N}=\mathrm{N}_{\mathrm{F}}+\mathrm{N}_{\alpha}+\mathrm{N}_{0} ; \mathrm{N}=9$ experiences

The equation (1) is given as follows $y=a_{0}+a_{1} x_{1}+a_{2} x_{2}+a_{12} x_{1} x_{2}+a_{11} x_{1}^{2}+a_{22} x_{2}^{2}+e$

$y$ represents the yield of essential thyme oil;

$x_{1}$ and $x_{2}$ are the coded variables respectively for the extraction time and the plant form;

$a_{i j}$ : are the coefficients of the model $(i=0,1,2$ and $j=1,2)$

The generation of the experience matrix as well as the statistical analysis of the results were done using MODDE software, version 6 .

\subsubsection{Extraction method}

The extraction was carried out by Clevenger hydrodistillation. $20 \mathrm{~g}$ of the plant material is immersed in a round flask filled with $266 \mathrm{~mL}$ of distilled water (enough to cover the plant material). The obtained essential oil is stored in a refrigerator at $4^{\circ} \mathrm{C}$ in glass tubes. The yield of essential oil is determined by the equation 2 :

$$
Y_{E O}(\%)=\frac{M_{E O}}{M_{d}} \times 100
$$

$Y_{E O}$ is the yield of essential oil (\%) ;

$M_{E O}$ : the mass of essential oil ( $\mathrm{g}$ ) ;

$M_{d}:$ is the mass dried plant material (g).

\subsubsection{Characterization of essential oil}

\subsubsection{Refractive Index}

The refractive index is determined using an ABBE refractometer. The apparatus is adjusted to give a value of 1.333 for distilled water at $20^{\circ} \mathrm{C}$ [16].

\subsubsection{Density}

The relative density is experimentally measured using a syringe $(1 \mathrm{~mL})$ and is calculated using the following equation [16]:

$$
d_{20}^{20}=\frac{m_{2}-m_{0}}{m_{1}-m_{0}}
$$

Avec: $m_{0}:$ mass of the empty syringe $(\mathrm{g})$;

$$
\begin{aligned}
& m_{1}: \text { mass of the filled syringe with distilled water }(\mathrm{g}) ; \\
& m_{2}: \text { mass of the filled syringe with essential oil }(\mathrm{g}) \text {. }
\end{aligned}
$$

\section{RESULTS AND DISCUSSION}

3.1. Statistical study of extraction results using hydrodistillation Clevenger

The obtained results by central composite design are summarized in Table 2.

Table 2. Results of the central composite design.

\begin{tabular}{cccccc}
\hline \multirow{2}{*}{ Run } & \multicolumn{2}{c}{ Extraction time } & \multicolumn{2}{c}{ Plant material } & \multirow{2}{*}{ Yield (\%) } \\
\cline { 2 - 4 } & $\begin{array}{c}\text { Coded Value } \\
\left(\mathrm{x}_{1}\right)\end{array}$ & $\begin{array}{c}\text { Real Value } \\
(\mathrm{min})\end{array}$ & $\begin{array}{c}\text { Coded Value } \\
\left(\mathrm{x}_{2}\right)\end{array}$ & $\begin{array}{c}\text { Real Value } \\
(\mathrm{min})\end{array}$ & \\
1 & -1 & 60 & -1 & unground & 1.61 \\
2 & 1 & 180 & -1 & unground & 1.70 \\
3 & 0 & 120 & -1 & unground & 1.43 \\
4 & -1 & 60 & 1 & ground & 01.2 \\
5 & 1 & 180 & 1 & ground & 1.23 \\
6 & 0 & 120 & 1 & ground & 01.1 \\
7 & 0 & 120 & 1 & ground & 1.05 \\
8 & 0 & 120 & 1 & ground & 0.95 \\
9 & 0 & 120 & 1 & ground & 0.90 \\
\hline
\end{tabular}




\subsubsection{Validation of the mathematical model}

The validity of the mathematical model [17] using MODDE 6 software consists of:

- Determine the coefficients $\left(\mathrm{R}^{2}\right)$ and $\left(\mathrm{Q}^{2}\right)$ which represent respectively the ability to predict the response of the model. The $\mathrm{R}^{2}$ and $\mathrm{Q}^{2}$ values are close to the unit (the lower limit value of $\mathrm{R}^{2}$ and $\mathrm{Q}^{2}$ is 0.8 and 0.5 respectively);

- Determine significant and insignificant factors;

- Study the interactions between factors;

- The last two validation steps are analysis of variance and residue analysis.

\subsubsection{Adequacy of the model}

Figure 1 shows the observed response against the predicted response, which represents the evaluation of the model. All the points are close to the diagonal. Thus, the experimental values are nearly to those predicted. The coefficients values of $\mathrm{R}^{2}$ and $\mathrm{Q}^{2}$ are 0.961 and 0.933 , respectively. These values are close to equal, so the model is adequate.

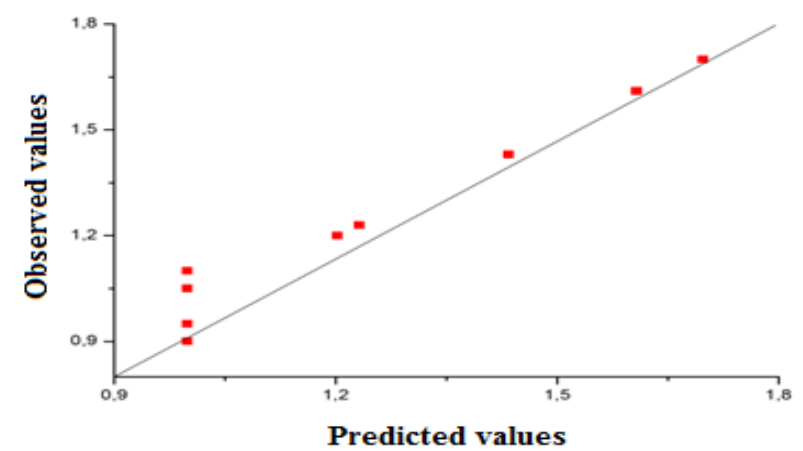

Figure 1: Observed response against the predicted response.

\subsubsection{Significant factors}

A factor is significant when its confidence interval represented by the vertical bar which does not intersect the horizontal axis [18]. Figure 2 shows the significant factors on the extraction yield which are the plant form and the extraction time.

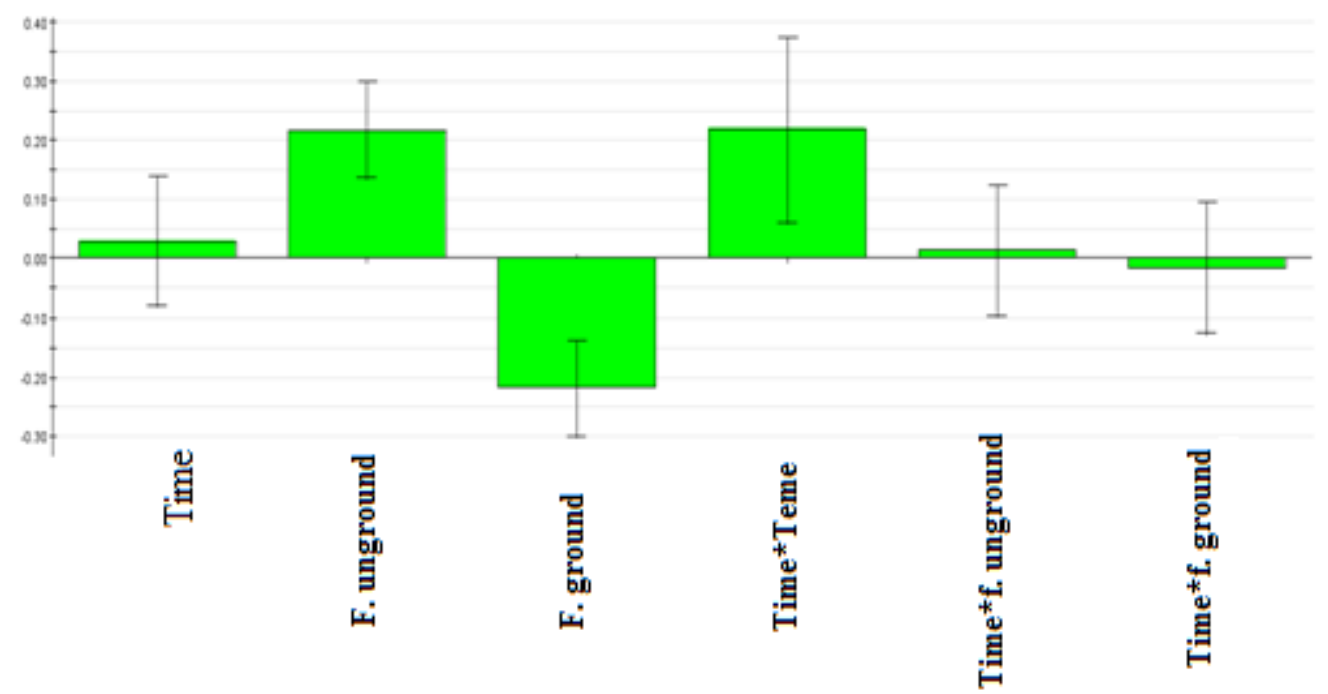

Figure 2: Histogram of influence of coefficients on essential oil yield

According to scientific literature, the effect of ground plant on the extraction yield differs according to the plant's nature and the localization of the secreting pockets of the essential oil.

Figure 2 shows that the unground form of the plant has a positive influence on the extraction yield of essential oil while the ground form has a negative influence. This is probably attributed to the localization of pockets of secreted essential oil on the surface. Indeed, histological studies carried out on several species of thyme confirm that the secretory hairs, very abundant on the plant, accumulate in their cytoplasms essences secreted under the cuticle [13]. This result attests that the cuticle or the external membrane, which constitutes the only barrier to the release of essential oils, is quickly ruptured at boiling point.

This result is in accordance with those obtained by Djerrari et al. 1986 [19]. They reported that grinding causes losses in the yield, especially compounds with the lowest boiling point. This can be explained by a loss through volatilization during grinding due to the destruction of secreting pockets since the storage sites of essential oils are on the surface.

\subsubsection{Analysis of variance}

Analysis of variance (Table 3) confirms whether or not the variables (factors) for modeling have a significant effect on the response. The Fisher test checks whether there is a relationship between factor and response, or if it is due to a random fluctuation of the responses in the experimental domain. The model is considered valid when the experimental Fisher $F\left(F_{o b s}\right)$ is greater than tab Fisher $F$ ( $F_{\text {crit }}$ ); the $\mathrm{p}$-value is close to zero. Therefore, the model is statistically significant and should be suitable for given response 
Table 3: Analysis of Variance.

\begin{tabular}{ccccccc}
\hline & Sum of square & DDL & Average square & $F_{\text {obs }}$ & $F_{\text {crit }}$ & $p$-value \\
\hline Regression & 0.616644 & 4 & 0.154161 & 24.622 & 6.388 & 0.004 \\
Residues & 0.0250445 & 4 & 0.00626112 & & & \\
Total & 0.641688 & 8 & 0.080211 & & & \\
\hline
\end{tabular}

\subsubsection{Residues study}

To develop a comprehensive and coherent statistical analysis of the model, it must be ensured that the residues are not important. For that, the evolution of the estimated residues with the predicted values must be accounted for. The description of the scatter points (responses) allows the verification of the model validity. The model is validated if the scatter points are arbitrarily distributed. On the other hand, if the distribution of the scatter points is well defined; it means that the variation of the answer is due to the residues. Figure 3 shows the evolution of residues with the studied factors. It shows random dispersion of residues.

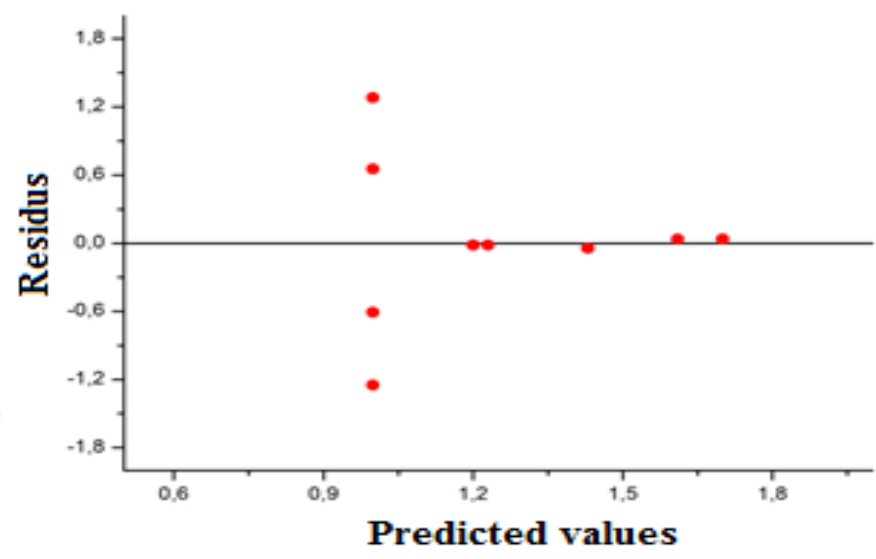

Figure 3: Evolution of residues against predicted value

\subsubsection{Optimization}

The optimization module (Table 4) provides possible solutions and indicates resolution near to the optimum.

Table 4. Resolution of the optimization using " optimizer " module

\begin{tabular}{cccc}
\hline Solutions & Extraction time (mn) & Plant form & Yield (\%) \\
\hline 1 & 60 & unground & 1.6078 \\
2 & 180 & unground & 1.6978 \\
\hline
\end{tabular}

Both optimal solutions given by the MODDE 6 software indicate that the unground plant form is the most suitable to get the best possible extraction yield. Besides, the results offer two extraction times 60 and $180 \mathrm{mn}$ for similar extraction yield values. From an economic point of view, it is better to choose the first solution, which provides $1.6 \%$ essential oil after 60 minutes. Indeed, for duration of 3 hours of extraction different wild species of thyme collected in the Middle Atlas, gave values of yields of essential oils of around $0.44 \%$ and $2.71 \%$, Belmalha et al [20]. Thymus numidicus from the Azzazga region (Kabylia) generated an average yield of $2.4 \%$ in 3 hours, results reported by Ghorab et al [14].

\subsection{Characterization of Thyme capitatus essential oil}

The physical and organoleptic characterization of the essential oil is part of the quality control process. The density of an essential oil is a crucial criterion for the quality evaluation. The refractive index value is also a very important criterion because it indicates high monoterpenes content that corresponds to a high refractive index and highoxygenated derivatives content. This later will produce the inverse effect [21]. The physical and organoleptic characteristics of Thymus capitatus essential oil are shown in Table 5 .

Table 5. The physical and organoleptic characterization of the Thymus capitatus essential oil

\begin{tabular}{cccccc}
\hline & Aspect & Coulour & Odour & Referactive index & $\begin{array}{c}\text { Density at } \\
20^{\circ} \mathrm{C}\end{array}$ \\
\hline $\begin{array}{c}\text { Thymus } \\
\text { capitatus }\end{array}$ & $\begin{array}{c}\text { Viscous } \\
\text { liquid }\end{array}$ & Ligh yellow & $\begin{array}{c}\text { Smell pungent and } \\
\text { sharp }\end{array}$ & 1.4854 & 0.8384 \\
\hline
\end{tabular}


The physical characteristics obtained show that the relative density and the refractive index values of the Thymus capitatus essential oil are in accordance with the pharmacopoeia and AFNOR standard as well.

\section{CONCLUSION}

Application of experimental design methodology through central composite design for optimization of Thymus capitatus essential oil using Clevenger hydrodistillation method was carried out. The choice of the extraction time and the form of the plant as variables influencing the yield led to nine experiments. Analysis of the optimization results shows that the unground plant form is the key factor to get the best extraction yield.

The optimum yield value of the essential oils given by the MODDE 6 software is $1.6078 \%$, this result is obtained in one hour of time for the unground plant; it is very close to that obtained by the experiment, which confirms the optimization efficiency. Moreover, investigations related to the exploitation and development of the plant is especially becoming competitive.

Therefore, the optimization result of the extraction yield obtained in our laboratory is appropriate. The effect of extraction time and plant form on the maximization of the yield could be beneficial and have a considerable economic impact since the same experimental conditions could be reproduced and extrapolated and will be followed by full production. The physical and organoleptic characteristics of thymus capitatus essential oil are in accordance with the applicable standards.

\section{REFERENCES}

1. BOULAGHMEN $\mathrm{F}$ et al, Composition chimique et activité antimicrobienne de l'huile essentielle extraite de Tyhmus guyonii de Noe d'Aflou-Algérie, Revue Agrobiologia, 2018; 8(1):853-862.

2. Rao J et al., Improving the Efficacy of Essential Oils as Antimicrobials in Foods: Mechanisms of Action. Annual Review of Food Science and Technology, 2019; 10

3. HENI S et al, Chemical composition and antibacterial activity of the essential oil of Thymus ciliatus growing wild in North Eastern Algeria, Journal of Applied Pharmaceutical Science 2015; 5(12):056-060.

4. Messara Y. et al., Chemical Composition, Antibacterial, and Antifungal activities of the Essential Oil of Thymus numidicus Poiret from Algeria, Phytothérapie, 2018; 16:163-168.

5. Wauquier J.P., P.T., Le développement des procédés de raffinage et petrochimie. Technip. Paris; 1975.

6. Herzi N. et al, Comparison of different methods for extraction from Tetraclinis articulata: Yield, chemical composition and antioxidant activity, Food Chemistry, 2013; 141(4):35373545
7. Sahraoui. N.et al, Optimisation par plan d'expériences de l'extraction de l'huile essentielle du (Thymus pallescens). International Journal of Scientific Research \& Engineering Technology, 2016; 85-93

8. Fadil M. et al, Optimisation des paramètres influençant l'hydrodistillation de Rosmarinus officinalis $L$. par la méthodologie de surface de réponse. J. Mater. Environ. Sci. 2015; 6(8):2346-2357

9. Olugbenga et al., Optimization of oil and pectin extraction from orange (Citrus sinensis) peels: a response surface approach. Journal of Analytical Science and Technology, 2018.

10. Goupy J., la méthode des plans d'expériences, optimisation. Edt. Bordas, Paris; 1988.

11. Saidj F, Extraction des essences du Thymus numedius kabylliica. Doctoral thesis, 2007, University M'hamed Bougara, Boumerdès, Algiers.

12. Roger et al., Effet du séchage de la matière végétale sur la composition chimique de l'huile essentielle de Ocimum basilicum L., Science et technique, Sciences appliquées et technologies, Vol. 1, n² 2, 2007.

13. Majdi A. et al., Tissue-specific gene-expression patterns of genes associated with thymol/carvacrol biosynthesis in thyme (Thymus vulgaris L.) and their differential changes upon treatment with abiotic elicitors, Plant Physiology and Biochemistry, 2017; 115:152-162

14. Ghorab H et al., Comparative compositions of essential oils of Thymus growing in various soils and climates of North Africa. J. Mater. Environ. Sci., 2014; 5(1)):298-303.

15. Saidj F, et al., Chemical Composition and Insecticidal Properties of Thymus numidicus (Poiret) Essential Oil from Algeria, Journal of Essential Oil Bearing Plants, 2008; 11(4):397-405.

16. AFNOR, « Recueil de normes: les huiles essentielles. Tome 2. Monographies relatives aux huiles essentielles »., AFNOR, : Paris,. 2000; 661-663.

17. SAPORTA, J.-J.D.J.F.G., «Plans d'expériences - Applications à l'entreprise ».(1997)

18. Fisher RA, Statical method for research work.. (1925),

19. Abdellatif D, Influence du mode d'extraction et des conditions de conservation sur la composition des huiles essentielles de thym et de basilic, in Biologie cellulaire et moléculaire. Sciences des aliments. Montpellier 2, 1986.

20. Belmalha S. et al, Caractérisation chimiques de certaines espèces de thym Marocain du Moyen Atlas (région de Midelt), Global Journal of Pure and Applied Chemistry Research, $2015 ; 3(2): 43-52$.

21. Fatiha A et al., Composition chimique et activité antimicrobienne des huiles essentielles de Thymus algeriensis Boiss. \& Reut. et Thymus ciliatus (Desf.) Benth. du Maroc, Biotechnol. Agron. Soc. Environ, 2010; 14((1)):141-148. 